\title{
J.P. Morgan Recruitment Practices in China and the Foreign Corrupt Practices Act: Legal Networking or Illegal Bribery?
}

\author{
Frank J. Cavico* \\ H. Wayne Huizenga School of Business and Entrepreneurship, Nova Southeastern University, Ft. Lauderdale, Florida, \\ $U S A$
}

\begin{abstract}
This article examined J.P. Morgan Chase and Company (J.P. Morgan) and its recruitment practices in China pursuant to the U.S. Foreign Corrupt Practices Act (FCPA). Certain key elements of the statute were explicated and illustrated in the context of the bank's hiring in China. The article found that J.P. Morgan has an arguable defense to legal liability based on the lack of evidence that the bank acted with the requisite "corrupt" intent. The article also provided an examination of the morality of J.P. Morgan's recruitment practices pursuant to three ethical theories. It was found that the bank was acting morally pursuant to Utilitarianism and Ethical Relativism, but immorally under Kantian ethics. The article supplied general recommendations for companies and specific ones to J.P. Morgan to avoid liability pursuant to the FCPA.
\end{abstract}

Keywords: Bribery, China, corrupt intent, ethics, Foreign corrupt practices act (FCPA).

\section{INTRODUCTION}

This article examines J.P. Morgan Chase \& Company (J.P. Morgan) and its employment recruitment practices in China (that is, the People's Republic of China, including Hong Kong). The bank's hiring practices are currently being investigated by the U.S. government to determine if the bank violated the U.S. Foreign Corrupt Practices Act (FCPA). The U.S. Department of Justice and the Securities and Exchange Commission are seeking to determine if the bank hired the relatives of high-level state officials in charge of large state enterprises in order to secure business from state companies in China. In essence, the U.S. government is trying to ascertain if J.P. Morgan committed an illegal bribe in violation of the FCPA.

The article, after this brief introduction, will provide some general information as to the challenges of doing business in China, and then specifically discuss what is known to date about J.P. Morgan's recruitment practices. The article then will analyze the bank's hiring in the context of the FCPA to determine key legal issues and how they might be resolved. In particular, the article will examine the following critical elements of the FCPA in the context of the J.P. Morgan situation: the transfer of "anything of value" requirement, the transfer to a "foreign government official", the "corrupt" or bad intent requirement, and the "knowing" of wrongdoing requirement. Next, the article will analyze ethically the bank's practices. The key ethical theory to be discussed will be Ethical Relativism; but two other important ethical theories - Utilitarianism and Kant's Categorical Imperative will also be addressed. The morality of the bank's practices pursuant to these theories will be ascertained. The

*Address correspondence to this author at the H. Wayne Huizenga School of Business and Entrepreneurship, Nova Southeastern University, Ft. Lauderdale, Florida, USA; Tel: 954 262-5096; E-mail: cavico@nova.edu article will then provide some general suggestions to companies as well as specific recommendations to J.P Morgan in avoiding legal liability pursuant to the FCPA. The article, finally, will conclude with a brief summary and conclusion.

The focus of this article is the U.S. statute - the FCPA. Initially, however, it must be noted that China also has laws prohibiting bribery [1, pp. 302-305]. One set of laws deals with improper payments to government officials and the other deals with commercial bribery between private people [2, pp. 1025-29]. Yet, according to Runnels and Burton [1, p. $303]$, the "... anti-bribery laws are not objectively and consistently enforced". Chow, Daniel [2] also notes that there are special and secretive legal procedures for handling bribery and corruption allegedly committed by members of the Communist Party. One would assume that any high-ranking official of a state-run business in China would be a Communist Party member. Though most interesting, an analysis of Chinese anti-bribery law and Communist Party procedures either generally or in the context of J.P. Morgan's recruitment activities in China will have to be an area for future research. Rather, as noted, this article will be limited to the U.S. law - the Foreign Corrupt Practices Act.

\section{BACKGROUND}

\subsection{Doing Business in China}

Today, the economy is truly a global one; as such, businesses operate in foreign host countries where the laws, moral norms, customs, and practices are at times much different from that of a company's country. Corruption and bribery unfortunately are global phenomena too. China is, of course, a major "player" as well as business center in the global economy, both as an exporter and importer and creditor; and thus many businesses have facilities, operations, and personnel in China, and many, many more do business there "virtually" or through local distributors, suppliers, and 
agents. Politically, China may be an authoritarian county ruled by the Communist Party but economically it is a very capitalistic, business-minded, and profit-oriented country. Runnels and Burton [1] point out: "Historically, a nation wary of FDI (foreign direct investment), China has embraced in the last twenty years a modern, market-oriented system that caters heavily to international business". However, "such change does not come without its share of challenges" [1].

This article focuses on one business, a U.S. bank, J.P. Morgan Chase \& Company (J.P. Morgan), doing business in China and the concomitant allegations of bribery, which is a form of global corruption, involving the bank and high level Chinese government officials. China, in particular, is deemed to be a "high risk environment" [3] to do business legally, because "...local laws, years old customs, and demands to partner with, or work through, local organizations can make conducting business a daunting process". Daniel [2] concurs, emphasizing that "China poses special risks" for multinational businesses due to the substantial involvement of an authoritarian state in economic, social, as well as political realms, and a business culture that tolerates corruption and bribery, including "favors given in order to secure a business advantage or build or fortify a business relationship". Complicating the legal and business situation, adds Daniel (2012, p. 1017), is the fact that "...in China...many persons that appear to be private or ordinary business persons will qualify as foreign officials". Gorman [3] further relates some of the legal challenges in doing business in China today:

Companies doing business in China must manage not just FCPA compliance but also a variety of local laws while competing with enterprises that are not focused on anticorruption compliance. China does not have any overriding statute such as the FCPA....There are, however, local laws that companies must consider including: PRC criminal law; interpretations of select courts, anti-unfair competition law; and certain interim provisions on prohibition of commercial bribery activities.... While contending with these laws, and maintaining FCPA compliance, business organizations must also compete with those who are not following the US statute (p. 1194).

Chow [2] adds that the FCPA “...applies with special force in China due to the coalescence of several factors: China's state-controlled economy, a pervasive culture in which gifts and favors are expected, and in which various forms of petty corruption are common and tolerated". Runnels and Burton [1] explicate the clash of culture and law in China, to wit:

China embraces deep-rooted traditions, some of which test the boundaries of the Western world's moral and ethical principles. Bribery...is a perfect example; it is not just common but runs rampant throughout China's business practices and is accepted as a valid means of doing business. China's economic ascendance and its cultural acceptance of bribery challenge the prevailing U.S. anti-corruption regime....U.S. companies operating in China encounter an ethics and compliance minefield, with bribery and corruption impeding successful business operations. Western companies that want to compete in China's booming market must understand unique cultural and legal processes that shape business transactions in that country, while at the same time not running afoul of U.S. law (p. 298).

Runnels and Burton [1] state that China has a "business culture where bribery occurs in the regular course of business" and where "bribery is built into the Chinese business culture" (p. 302). Consequently, the increasing globalization of business has thrust many U.S. businesses into a legal, ethical, and practical morass in China. And that morass is where J.P. Morgan has found itself.

\subsection{J.P. Morgan Recruitment Practices in China}

The narrow focus of this article is on a U.S. business, a bank, J.P. Morgan Chase \& Company (J.P. Morgan), doing business in China in the context of the FCPA. In 2013, the Wall Street Journal [4], the New York Times [5], and the Miami Herald [5, 6] reported that J.P. Morgan is being investigated by the U.S. government for allegedly bribing Chinese government officials in violation of the Foreign Corrupt Practices Act (FCPA). Both the Department of Justice and the Securities and Exchange Commission (SEC) have opened bribery investigations to determine whether the bank's practice of giving jobs to the children of high-level, powerful government officials in order to help the bank obtain lucrative business deals with the Chinese government and/or entities dominated or controlled by the government. The New York Times [5] reported that recruitment effort, called the "Sons and Daughters" program, initially arose around 2006 and seemingly peaked around 2009. The bank had been losing several large business deals to competitors who were engaging in hiring of relatives of officials of state enterprises in China; and the "Sons and Daughter' s" program was the bank's response. At the time the China economy was "booming" and state enterprises were using banks to raise billions of dollars in stock and debt offerings; but, according to the New York Times [5], "J.P. Morgan was falling further behind in capturing that business".

In one recruitment example, J.P. Morgan hired the son of a former Chinese banking regulator who is now the chairman of the China Everbright Group, which is a state-controlled financial conglomerate. Once the chairman's son was hired, the bank secured several contracts from the Chinese conglomerate [4-6]. To further illustrate, the Hong Kong office of J.P. Morgan also hired the daughter of a Chinese railway official. The official is also being investigated by the Chinese government for purportedly awarding government contracts in exchange for cash bribes. The China Railway Group is a state-controlled construction company that builds railways for the Chinese government. The Railway Group was in the process of selecting J.P. Morgan to advise it on plans to become a public company [4-6]. The typical "Sons and Daughters" job paid between $\$ 70,000$ to $\$ 100,000$ a year [5]. The New York Times [5] reported that the "Sons and Daughters" program apparently had some success, as in 2009 J.P. Morgan was $13^{\text {th }}$ among banks in obtaining business in China; but by 2013 the bank had risen to $3^{\text {rd }}$ in market share in China. Accordingly, a key question emerges as to whether there is a sufficient and demonstrable causal link and connection between J.P. Morgan's recruitment practices in China and its growth in business in that country. Did the bank wrongfully direct business to itself by means of the hiring? Specifically, are the bank's recruitment practices 
illegal bribes in violation of the Foreign Corrupt Practices Act or merely "good" business networking practices?

\subsection{Legal Analysis}

The Foreign Corrupt Practices Act is a very important U.S. statute that makes bribery of foreign government officials in order to secure business a serious criminal wrong, with sanctions including imprisonment for committing a felony, as well as criminal law and civil law monetary fines against individual transgressors and companies. The statute has extraterritorial effect in that the government can prosecute as well as proceed civilly against companies and their personnel who bribe government officials overseas (assuming the government can obtain adequate evidence of wrongdoing) [7-10]. The FCPA has two major components: an anti-bribery part that makes it illegal to provide anything of value to officials of foreign governments with the wrongful or "corrupt" intent to obtain business, and an accounting component that requires companies to maintain books and records that fully and accurately reflect transactions with foreign government officials and also to maintain proper internal controls to endure the integrity of the records and accounting processes [8]. The legal analysis herein will deal with the first part to the FCPA - the statute's anti-bribery provisions.

The U.S. government is investigating J.P. Morgan, as it has and is doing to other companies, to determine if the bank violated the Foreign Corrupt Practices Act, which makes the payment of a bribe, either in the form of money or "anything of value", to a foreign government official, a serious crime as well as a civil wrong [7-9]. Typically, the Justice Department brings criminal prosecutions for violation of the law; and the Securities and Exchange Commission proceeds against wrongdoers civilly. The government is very concerned that U.S. companies are not only hiring the children and relatives of Chinese government officials, but that the U.S. companies are hiring them for "no show" or fake jobs as an indirect way of concealing the transfer of illegal cash payments to the government officials [4-6]. That is, the government is investigating to determine if the hiring of relatives amounts to an illegal bribe pursuant to the FCPA.

Neither the U.S. investigation, so far, nor Chinese government documents and public records, definitely link J.P. Morgan's hiring practices to its ability to secure business. Moreover, there is no evidence to date that any of the employees hired were unqualified or that the jobs were fake ones. Nor is there any evidence yet that the employees themselves helped J.P. Morgan obtain business [4-6]. Nonetheless, U.S. investigators suspect that the bank routinely hired young associates who came from well-connected Chinese families whose members ultimately offered JPMorgan state consulting and other business for the hiring [4-6].

The first legal point to address is whether the officials allegedly being bribed by J.P. Morgan are in fact "foreign government officials", as the statute requires. However, as Chow [2] points out, the U.S. government takes an expansive view pursuant to the FCPA as to who in the host country qualifies as a government official. Accordingly, if a Chinese company involved in the J.P. Morgan bribery allegations is state-owned, wholly or partially, state-dominated, statecontrolled, or state-subsidized, the officials therein, who are typically high-level ones with discretionary power over contracts and business, would be deemed to be foreign government officials [2]. As Chow [2] warns: "These expansive definitions of state-owned and state-controlled enterprises as instrumentalities of the state and employees of such entities as foreign officials create significant risks for companies under the FCPA".

The second legal point to address is whether the hiring is in fact an illegal bribe pursuant to the FCPA. The statute does not specifically use the word "bribe" but rather can deem a criminal and civil wrong based on the transfer of "anything of value" to the foreign government official [7, 8]. That key term, "anything of value", under the FCPA has been very broadly construed by the Department of Justice and the SEC. Chow [11] emphasizes that the "giving of 'anything of value' to a foreign official in order to obtain or retain business does not have to be in cash. The DOJ has interpreted the term 'anything of value' in an expansive manner". Accordingly, regarding China, Chow $[9,11]$ explains that:

...paying for executive training programs at US universities for Chinese foreign officials when the training was not specifically related to the company's business could fall under this definition. Other examples include payment of tuition and expenses for educational programs in the United States for Chinese officials, payment of tuition for an MBA degree, arranging for a paid internship for a daughter of a Chinese official, and payment for Sightseeing trips in the United States to tourist attractions such as the Grand Canyon and Las Vegas. The issue that is raises by this expansive definition is that Chinese government or business officials often ask for non-monetary favors from friends and other business associates (p. 1187).

Thus the hiring one's relatives should suffice as a transfer of something of value, though indirect [7]. Actually, even an offer of employment should be adequate to satisfy the "value" requirement [8]. The term "foreign officials" is also broadly defined by the FCPA; as such, any person who receives at least a part of his or her salary from the public treasury of a foreign government is considered to be a foreign government official [8]. Consequently, the Chinese officials in the J.P. Morgan case, as high-level employees of state-owned or -dominated companies, would certainly be construed as foreign government officials for FCPA purposes.

However, in order to demonstrate a violation of the FCPA the government must also prove that the entity that paid the money or transferred something of value, directly or indirectly, to the foreign government official did so with a "bad" or corrupt intent; that is, the intent was to wrongfully direct business to one's company or firm by inducing a person, a Chinese government official in the case herein, to misuse his or her official position to grant the contract or business to the bank, which perhaps based on objective standards it did not deserve [8, 12]. Under the old English common law, this requisite bad or corrupt intent, the classic "evil mind", was called "scienter" [7-9]. The essence of the "corrupt" intent is to obtain some type of unearned and undeserved preference or to otherwise accomplish some other unlawful result. However, there is no legal requirement that the transfer of "value" violate the law of the host country [8]. 
Yet proving such "corrupt" intent is very difficult for the government to do, especially in a criminal case where the evidentiary standard is "proof beyond a reasonable doubt" (as opposed to a "preponderance of the evidence" standard for a civil case) [7, 12]. Evidence, of course, can be direct in the form of witnesses and documents or indirect or circumstantial [7]. For example, the closer the hiring was to the obtaining of the contract or benefit, the easier it will be for the government to show an improper nexus or connection, at least by circumstantial evidence. Similarly, the closer the relationship between the recipient of a company's largess and the foreign government official the more a jury can infer corrupt intent. To further illustrate in the case herein, even if the bank's hiring of the children of a government official was motivated by a desire to create "good will", to "network", and to curry favor with the foreign official, that mind-set does not necessarily mean that the hiring is corrupt and a bribery crime has been committed, assuming that otherwise the hiring was appropriate. Actually, as reported by the Wall Street Journal [13, p. C1], J.P. Morgan Chairman and Chief Executive, James Dimon, stated in a January 2014 interview on CNBC that "it has been a 'norm for years' for banks to hire 'sons and daughters of companies' and to give them 'proper jobs' without violating the law". The bank has long insisted that its program is a lawful one [5].

Consequently, the government is looking for some type of documents or witnesses that would show or testify to a quid-pro-quo, that is, a causal connection or link between the hiring and the business opportunities [12]. Was the business obtained wrongfully as a result of the hiring of the relatives, and thus was the requisite corrupt intent was present [14]? Those are key legal issues. As Chow [2] explains: "Asking for favors, such as helping a child or relative, is a common practice in China and most people in China not only accept the practice but see nothing wrong with the practice. However, such a practice could trigger liability under the FCPA, especially where there is a quid pro quo, i.e., the obtaining of business in return for a non-monetary favor given to a Chinese official". From an evidentiary standpoint, what might be damaging to the bank is a series of emails reported by the Wall Street Journal [15] that the bank hired the son of the Chinese Commerce Minister despite the fact that the son did poorly on his job interview, did not competently handle his work visa process, sent a sexually inappropriate email to a human resource officer, and was described as "immature, irresponsible, and unreliable". Furthermore, the Wall Street Journal [15, p. A1] indicated that the Commerce Minister said he would "go extra miles" for the bank if the bank hired his son.

Another fact that might bolster the government's evidentiary case is that the bank apparently was warned in 2011 that there might be some problems with its "Sons and Daughters" hiring program in China as well as Asia. The Wall Street Journal [13] reported that in 2011 a bank official in Asia alerted bank legal and compliance officers in New York regarding anonymous accusations that the local bank officials recruited either a "prominent" son or daughter of a "senior Chinese official" in order to help the bank obtain and investment-banking contract. J.P. Morgan officials "later discussed those accusations" but "dismissed them"; yet nonetheless the bank's board of directors approved addi- tional anti-corruption measures, including proposing changes to hiring practices in Asia [13]. What also might assist the government in securing evidence is the "whistleblowing" provision in the Dodd-Frank financial reform law of 2010 which grants employees (as well as other individuals including company "outsiders") who undercover and disclose fraud and other illegality, including violations of the FCPA, to government regulators. These whistleblowers can get a reward of $10-30 \%$ of the monetary penalties collected by the government $[16,17]$.

Another legal requirement as per the FCPA that likely could arise in the J.P. Morgan situation is the "knowing" requirement. That is, pursuant to the statute, there must be evidence that the transfer of value occurred by a party "knowing" that it was given directly or indirectly to the foreign government official [8]. The objective of this "knowing" requirement is to prevent companies from claiming ignorance of improper payments by their employees, agents, independent contractors, and subsidiaries to foreign government officials; that is, to prevent companies from using the "ostrich" (the "head-in-the-sands" approach) to avoid culpability. Of course, if a company actually knew of the improper payments or authorized or directed them to the foreign government officials there will be legal liability [8]. Moreover, if a company acted in reckless disregard of the facts, or in conscious indifference thereto, or was aware of a high probability or substantial likelihood of illegal payments, then the "knowing" requirements will be satisfied [8]. As Gorman [3] warns: "Indeed, the company can quickly find itself in the middle of a DOJ or SEC FCPA investigation tied to the actions of local agents and affiliates".

In the J.P. Morgan situation herein, as mentioned, the fact that the company might have been warned by its personnel in Asia that its hiring practices, perhaps some of which were inappropriate, occurred would surely be evidence that the bank met the "knowing" requirement regarding the purportedly illegal payments. To further substantiate the "knowing" requirement is evidence that the bank in fact had apparently created the program at a high-level and had a name for the program that clearly indicated its intent; the recruitment effort, as noted, was called the "Sons and Daughters" program $[3$, p. 1207). The very name of the recruitment program indicates that higher level bank executives at headquarters not only knew about the program but perhaps created it, authorized it, and directed the program. Moreover, the New York Times [5] reported that bank executives tracked how their hires of well-connected employees led to business with Chinese government entities. So, it appears that it will be difficult for the bank to attenuate the "chain of causation" and to say defensively it was "merely" its "bad" local personnel in China engaging in any wrongdoing

Moreover, it should be pointed out the U.S. government has had some success in the past with such bribery investigations. In 2008, Siemens settled a bribery case with the SEC, admitted wrongdoing, and paid an $\$ 800$ million fine for hiring the daughter of a telecommunications regulatory official in Bangladesh, as well as the nephew of an official in the country's telecommunications ministry, in return for a project contract [4]. In 2010, Daimler was accused of paying the wife of a Chinese official through a fake consulting contract in return for a contract to sell commercial vehicles to the 
Chinese government. The company also admitted wrongdoing, and settled the allegations with the Justice Department [4]. And in 2011, the Justice Department alleged that the company placed the wives of Mexican government veterinarians on its payroll even though the wives did not perform any services for Tyson. The veterinarians were responsible for certifying Tyson products for export. Tyson also admitted wrongdoing in its settlement with the Justice Department [8]. The Wall Street Journal [14] and the New York Times [5] indicated that U.S. government regulators are now also looking at the hiring practices of other banks in Asia, for example, Citigroup, Goldman Sachs, Morgan Stanley, Deutsche Bank, UBS, and Credit Suisse, as apparently there are other banks who too have been hiring the family members of current or former government officials. As of the writing of this article, neither J.P. Morgan nor any of the aforementioned banks have been accused of any legal wrongdoing based on their recruitment practices in China pursuant to the Foreign Corrupt Practices Act. However, the New York Times [5] reported that several J.P. Morgan personnel in Hong Kong have now hired criminal defense attorneys.

\subsection{Ethical Analysis}

In addition to determining if J.P. Morgan was acting legally in China, this article will now examine if the bank was acting morally pursuant to ethics. Clearly, there are ethical challenges to doing business in China. So, what is "ethics"? Ethics is the branch of philosophy that is used to reach moral conclusions as to "good" or "bad", "right" and "wrong", and "moral and immoral". The field of ethics consists of the intellectual theories and principles that one uses to reason to moral conclusions [9]. The three ethical theories that will be addressed in this article are Ethical Relativism, Utilitarianism, and Kant's Categorical Imperative. These theories are all Western-based, secular, and reasoned-premised ethical theories. Though it would be most interesting to see how Confucian ethics would apply to J.P. Morgan's recruitment practices in China, such an analysis must be saved for future research.

Ethical Relativism is an ethical theory first created by the ancient Greeks and Romans. It is a societal-based ethics; that is, whatever a particular society or culture believes is good, right, and moral is good, right, and moral for that society. Accordingly, moral standards and precepts are determined by societal values, customs, and mores. So, if one is an Ethical Relativist, all one has to do is to ascertain the societal and cultural moral standards and then adopt and conform to them, and one will be acting morally, at least in that society. So, as the very old saying goes: "When in Rome, do as the Romans" [9]. Of course, being an Ethical Relativist and acting in conformity with societal moral standards is not a defense to the FCPA, as one can be said to be acting morally, but not necessarily legally.

These ethical challenges of doing business legally in Chinese society are highlighted by a report, based on a survey of companies currently conducting business in China, by the U.S. China Business Council, titled "Best Practices for Managing Compliance in China", which in pertinent part found: "Practices normally considered acceptable in the U.S. may not only be allowed in China, but may even be strongly encouraged by local cultural conventions" [3]. Runnels and Burton [1] go further and declare that bribery not only "runs rampant throughout China's business practices", but also, morally and ethically, "is accepted as a valid means of doing business". The acceptability of these bribery practices as right and proper conduct, moreover, will give credence to the precept that these are morally acceptable practices in Chinese society. Therefore, the morality of J.P. Morgan's recruitment practices is complicated ethically, and not just for the government but also for companies doing business in China as well as other developing countries, due to the fact that the hiring of relatives of prominent people can be, and appears to be, a well-established, "correct", customary practice and societal norm [4]. As Chow [2] points out: "Asking for favors, such as helping a child or relative, is a common practice in China and most people in China not only accept the practice but see nothing wrong with the practice". The creation and maintenance of good personal relationships, called "guanxi", is also a paramount feature of Chinese culture and thus an additional factor that contributes to bribery [1]. Though the hiring of relatives is typically called by the pejorative term, nepotism; nonetheless, if such a practice is considered to be appropriate and right in a society based on its cultural norms, as it appears to be in China, the practice would be deemed a moral one pursuant to Ethical Relativism. Accordingly, J.P. Morgan can be said to be acting morally, at least pursuant to the ethical theory of Ethical Relativism, in its recruitment practices in China.

Utilitarianism is a more modern ethical theory, created by the English philosophers and social reformers, Jeremy Bentham and John Stuart Mill. Utilitarianism is at times called a "consequentialist" ethical theory because morality is determined by a preponderance of good results that will be produced from an action. So, the action itself is neutral; it is the consequences that determine morality. One surely is familiar with the basic tenet of Utilitarianism: An action is moral if it produces "the greatest amount of good for the greatest number of people". Challenging aspects of this ethical theory are that one has to predict the consequences - good and bad that will result from an action and then measure and weigh them to determine if the good outweighs the bad, and thus the action is moral, or the bad outweighs the good, and consequently the action is immoral. As for the predictive element, the Utilitarians would say to base predictions on probable or likely or reasonably foreseeable consequences; and do not guess or speculate. As to the measuring, be as objective and scientific as possible, they would say. One positive feature of Utilitarianism is that it is a very egalitarian ethical theory; that is, all people get treated equally; since everyone is a human being and feels pleasure and pain, everyone gets "counted" in this Utilitarian "calculus". That is the "good news"; however, the "bad news" is that when the counting is done there may be more good - pleasure-happinesssatisfaction than bad - and thus the action is moral. Yet there are still some bad consequences, perhaps to a minority of people, but the bad consequences were outweighed by the good; the "bad" got counted, at least. As such, under Utilitarianism, to state another old maxim that the readers are familiar with: "The end justifies the means". And if the "end" is the "greater good" the fact that there are some bad consequences as in the means is permissible under this ethical theory [9]. 
In the J.P. Morgan situation herein, to do a Utilitarian analysis of this alleged bribery scheme, one would first have to state all the stakeholders involved in the bank's recruitment practices, to wit: bank executives and employees in the U.S. and China, shareholders, the bank's partners and agents in China, the Chinese government officials, their relatives getting the jobs, the other candidates for employment who did not get the positions, the U.S. government, the Chinese government, U.S. society and economy, Chinese society and economy, and the competing banks. For each of these stakeholder groups an analysis would have to be made of the good vs. the bad consequences of J.P. Morgan's recruitment practices in China based on the facts that have been discerned and the predictions of reasonably foreseeable future consequences. Though it is beyond the scope of this succinct article to do a full Utilitarian analysis [see 7-9 for a complete Utilitarian analysis of the morality of bribery in an international context), it appears that a great deal of "good" will emanate from the bank's recruitment practices. Of course, the qualified, not well-connected job candidates will feel "pain" by not getting the positions, but they likely will find employment elsewhere; and the U.S. government is distressed as it feels its FCPA law may have been violated; and J.P Morgan has to deal with the negative publicity and the government investigation and possible lawsuit, assuming the government can get enough evidence; but the bank does have an arguable and strong defense that is motive was not "evil" or "corrupt", as it was merely networking in China as its competitors did. The bank surely is doing "good" by substantially increasing its business in China, which, of course, causes "pain" to its competitors (but they have had their chances to "network" too). Otherwise, a great deal of "good" as well as "good will" is going to flow to all the other stakeholder groups by J.P. Morgan providing its expert financial consulting and banking services to state companies in China. Money and economic benefits will go to shareholders, employees, bank third parties, and to the U.S. and Chinese governments and societies. Accordingly, it appears that there are more positive benefits resulting from J.P. Morgan's recruitment practices in China; and thus the bank's alleged "bribery" is moral, at least pursuant to the Utilitarian ethical theory.

Another modern theory of ethics in Western Civilization is the ethics of the German philosopher, Immanuel Kant. There then appears an immediate problem in ethics in Western intellectual thought, as Kantian ethics is diametrically opposed to Utilitarians. The latter would say to base ethics on the consequences of an action; but Kant says to disregard consequences and instead to concentrate on the action itself and to make sure the action passes a formal test, which Kant calls the Categorical Imperative. Consequently, there is a major conflict in ethics in Western Civilization, which means that one can have two differing moral conclusions by the application of two different ethical principles stemming from these two modern and major ethical theories. Such is the nature of Western ethics! As to the Categorical Imperative, Kant means that by "Categorical" his principle, if one reasons it out like he did, is the supreme, absolute, and only ethical test for morality. And by "Imperative" Kant means that one must have the strength of character, that is, the "good will", to do what one knows is morally right (for example, to "blow the whistle" on bribery by one's firm re- gardless of the consequences) and not do what one knows to be morally wrong (to continue the example, to bribe) [9].

So, how does one determine the morality of an action pursuant to the Categorical Imperative? There are various aspects of Kant's supreme ethical principle. For the purposes of this article, two will be explicated and applied to J.P. Morgan's actions. The first is called the Kingdom of Ends test. For an action to be moral pursuant to this test it must treat all people affected by the action with dignity and respect which they deserve as worthwhile human reasons. Consequently, if an action is demeaning, disrespectful, and treats people as a mere means, an instrument, or a tool, even to achieve a greater good, the action is immoral. The second is called the Agent-Receiver test, which is the "Golden Rule" of religion made secular by Kant. According to this test, if one did not know whether one would be the giver/agent of an action or on the "receiving end" and one is a rational person would one be willing to accept the action [8]. Now, as to J.P. Morgan and the first Kantian test, if one feels it is demeaning and disrespectful to the otherwise qualified but not well-connected job applicants who failed to get the positions because they were just the "sons and daughters" of poor parents, then the action is immoral. Moreover, if one feels that the bank's actions are disrespectful and demeaning to the successful job applicants themselves who were perhaps chosen solely or mainly because of their connections to their highly-placed relatives, then one can say that J.P. Morgan just used them as a mere means to get business with the state (though, not to be cynical, at $\$ 100,000$ a position the "Sons and Daughters" may not care). As to the Agent-Receiver test, if one is a rational person and one did not know if he or she would be a qualified job applicant who is merely a poor "son or daughter" as opposed to a very well-connected "Son or Daughter", who gets the well-paid and coveted position, would one find that result morally acceptable. One would think not. Accordingly, we have an ethical situation, which one typically finds in Western ethics, whereby an action is moral pursuant to Utilitarianism (where you can have some "bad" so long as there is more "good") but immoral pursuant to the much more strict Kantian ethical formulation (which focuses on the action itself), So, is one a Utilitarian, or a Kantian, or for that matter an Ethical Relativist? Or is one a bit "sophisticated" in the use of ethics (as per the relativism of the Sophists in ancient Greece) and thus one will chose the ethical theory that will most likely lead to the moral conclusion that one desires!

Therefore, as to the morality of J.P. Morgan's recruitment practices in China, the answer is - it depends on the ethical theory being used (and with Ethical Relativism being a very "convenient" one due to the prevalence of Chinese societal norms approving of the bank's practices). The discerning reader, therefore, is free to make his or her own principled-based moral conclusions based on the ethical theories examined herein. Yet, as noted, morality is not a defense to legal liability pursuant to the FCPA. Accordingly, in the next section of this article, certain general and specific recommendations will be offered to avoid legal liability by companies and J.P. Morgan.

\subsection{Recommendations}

As to general recommendations to avoid legal liability pursuant to the FCPA, the best place to look is the Depart- 
ment of Justice (DOJ)/Securities and Exchange Commission (SEC) Guide regarding the FCPA. The Guide advises that the following principles and practices be adhered to:

- The establishment by high-level executives of a corporate culture of ethics and integrity.

- The creation of a code of conduct or ethics that specifies proper and improper practices, responsibilities for compliance, internal controls and procedures, and auditing and documentation practices.

- Assigning responsibility for the compliance program to senior high-level executives.

- Assessing the risks of non-compliance by examining the business opportunity, the country, the industry sector, potential business partners, the level of involvement with government, and the amount and type of government regulation and oversight.

- Communicating the code of conduct and training personnel in code provisions and compliance procedures as well as regularly updating the code and compliance system.

- Providing incentives for compliance as well as sanctions for non-compliance.

- Educating partners, agents, consultants, and other third parties as to the code and compliance responsibilities.

- Establishing a confidential reporting system for code violations [3].

Chow, Daniel [2] also strongly advises that a company's legal compliance program be not only set up in the U.S. but also in China under the direction and supervision of a highlevel executive stationed in China and that training and other aspects of the program be conducted in China. Otherwise, Chow [8] declares: It will be "futile".

Specifically with regard to J.P. Morgan, legally, it is not against the law for U.S. companies to hire the relatives of government officials in China and elsewhere, but it is illegal to indirectly bribe government officials pursuant to the Foreign Corrupt Practices Act. A critical element of the law, as emphasized is the requisite "corrupt" intent; and important factors in determining such intent are whether a legitimate job actually existed (as opposed to, as we say in New Jersey, where this author was born and raised, a "no-show" job), whether the family member of the high level government official was in fact qualified for the position, and whether when hired he or she was a suitable employee. Proof of those matters will show that the bank was merely engaged in goodold-fashioned "networking" and "politicking" and not bribery. Other key legal issues, and possible defenses for J.P. Morgan, are whether the hiring of relatives of officials is construed as a transfer of value to the official and whether J.P. Morgan officials had the requisite knowledge of any such hiring by their personnel in Asia.

The legal, ethical, and practical situation is complicated since the hiring of relatives of prominent people, as emphasized, can be a well-established practice and societal norm in China [4]. In addition, there can be good and legitimate reasons for hiring the relatives, such as their good education, perhaps at "top" Chinese and U.S. and other foreign schools, broad experience, as well as the networking connections, which may not involve any illegality or impropriety [4]. Hughes (2014, p. 39), moreover, asserts that there is a "tension in the law of bribery" caused by the corrupt intent requirement that forms the heart of the statute, that is, "the dominant quid pro quo definition of bribery is intuitively over-inclusive. Juries understand that some morally innocent behavior can be classified as a bribe, and they recognize the need for some extra ingredient to separate the truly corrupt and blameworthy actions from those that merely violate the letter - but not the spirit - of the law". Such an interpretation may be beneficial to J.P. Morgan if the J.P. Morgan jury, if the case comes to that point, is a "Hughes jury".

Accordingly, for avoiding legal liability, factors that would help a company, such as J.P. Morgan, defend itself before a jury from bribery charges would be proof that there was a vacant position initially (as opposed to the company having created a new position for the official's relative), that the relative was qualified to fill the position, and that the relative performed the duties of the position in an adequate manner. The preceding factors would demonstrate that the bank's purpose was merely to engage in networking, an acceptable and established business practice, and as such to hire very good as well as very well-connected employees; and thus that J.P. Morgan's motive was not bad or "corrupt". The presence or absence of wrongful intent is at the heart of the FCPA and concomitantly is the crux of the J.P. Morgan government investigation.

\section{CONCLUSION}

Plainly, in the international business arena today certain types of payments, direct and indirect, to foreign government officials are not only expected but also accepted as a way of doing business in many countries. The Foreign Corrupt Practices Act prohibits and criminalizes these payments if the requisite elements of the statute are demonstrably present. This article has emphasized that a critical component pursuant to the FCPA to the classification of a payment or the transfer of something of value as a bribe is the requisite bad intent, purpose, or aim of the person or entity making the payment or transferring value to the foreign government official. The statute is not the Foreign Practices Act but the Foreign Corrupt Practices Act (emphasis added). The FCPA, therefore, does not prohibit all transfers of "anything of value" to foreign government officials; rather, what is outlawed is the payment or transfer with the corrupt motive to receive some type of preferential business treatment that one is not ordinarily entitled to receive. That is, there must be evidence of the classic quid pro quo - the critical link between the conduct and the benefit. This article has attempted to explicate several key requirements of the FCPA in the context of the J.P. Morgan situation in China. It appears that the legal case against J.P. Morgan will hinge on the essential finding of corrupt intent; that is, that the bank wrongfully directed business to itself by means of the hiring of the sons and daughters of the high-level Chinese government officials, which very well could be construed as a bribe pursuant to the FCPA. And regardless of the legal outcome of the J.P. Morgan investigation, a determination as to the morality of the bank's practices must be adduced. Accordingly, this article applied Ethical Relativism as well as Utilitarian ethics and Kant's Categorical Imperative to seek to determine the 
morality of the bank's practices. The bank's actions were found to be moral pursuant to Ethical Relativism and Utilitarianism, but immoral under Kantian ethics. Finally, the article provided some general suggestions to companies doing business overseas and specific recommendations to J.P. Morgan on how they can avoid liability pursuant to the FCPA.

As to the specific focus of this article, the outcome of the J.P. Morgan situation in China under eh FCPA is uncertain, as the government is still investigating as of this writing; and the key legal issue emerging from the investigation will hinge on a finding of the presence or lack of corrupt or bad intent in the bank's recruitment practices. As the old maxim says, "the jury is still out" on the J.P. Morgan "case". Yet one point is evident, and that is companies seeking influence and business by this type of "networking" or nepotism now may find themselves subject to bribery investigations and perhaps prosecution by the U.S. government pursuant to the Foreign Corrupt Practices Act. That is the "moral" of the continuing J.P. Morgan recruitment saga in China.

\section{ABOUT AUTHOR}

Frank J. Cavico is a Professor of Business Law and Ethics at the H. Wayne Huizenga School of Business and Entrepreneurship of Nova Southeastern University in Ft. Lauderdale, Florida. He has been involved in an array of teaching responsibilities, at the undergraduate, master's and doctoral levels, encompassing such subject matter areas as business law, government regulation of business, constitutional law, administrative law and ethics, labor law and labor relations, healthcare law, and business ethics. In 2000, he was awarded the Excellence in Teaching Award by the Huizenga School; and in 2007 and 2012, he was awarded the Faculty Member of the Year Award by the Huizenga School of Business and Entrepreneurship; and in 2014 he was named Professor of the Year by the Huizenga School. He holds a J.D. from the St. Mary's University School of Law and an LL.M from the University of San Diego, School of Law; and is a member of the Florida and Texas Bar Associations. He is the author and co-author of several books and numerous law review and management journal articles.

\section{ACKNOWLEDGEMENTS}

Declared none.

\section{REFERENCES}

[1] Runnels MB, Burton AM. The foreign corrupt practices act and new governance: incentivizing ethical foreign direct investment in China and other emerging nations. Cardozo Law Rev 291; 34: 295 328.

[2] Chow D. The interplay between China's anti-bribery laws and the foreign corrupt practices Act. Ohio State Law J 2012; 73: 1015-37.

[3] Gorman TO. Asia-pacific issue: panel on China and the FCPA: emerging trends in FCPA enforcement. Fordham Int'1 L J 2014; 37 : 1193-213.

[4] Palazzolo J, Matthews CM, NG S. Nepotism: When is it a crime? Wall St J 2013: B1, B2.

[5] Protess B, Silver G. On Defensive, JP Morgan hired China's elite. The New York Times 2013. [Retrieved January 10, 2015]. Available from: http://dealbook.nytimes.com/ 2013/12/29/on-defensivejpmorgan-hired-chinas-elite/

[6] Silver- GPB, Barboza D. Hiring in China by JP Morgan under scrutiny. The Miami Herald 2013 August 18; 4A.

[7] Cavico FJ, Mujtaba BG. Business Ethics: the moral foundation for effective leadership, management, and entrepreneurship. $3^{\text {rd }}$ ed Boston, Massachusetts: Pearson Publishing Company 2013.

[8] Cavico FJ, Mujtaba BG. Baksheesh or bribe: cultural conventions and legal pitfalls. Davie, Florida: ILEAD Academy 2011.

[9] Cavico FJ, Mujtaba BG. Legal challenges for the global manager and entrepreneur. $2^{\text {nd }}$ ed. Dubuque, Iowa: Kendall Hunt Publishing Company 2014.

[10] Mujtaba BG. Managerial skills and practices for global leadership. Florida, ILEAD Academy 2014.

[11] Chow DCK. Asia-pacific issue: Panel on China and the FCPA: three major risks under the foreign corrupt practices act for U.S. multinational companies doing business in China. Fordham Int'l L J 2014; 37: 1183-91

[12] Hughes BT. The crucial "corrupt intent" element in federal bribery laws. Calif West Law Rev 2014; 51: 25-54.

[13] Glazer E, Fitzpatrick D, Eaglesham J. J.P. Morgan was warned on hiring. Wall St J 2014 October 23; pp. C1, 2.

[14] Curran E, Eaglesham J. Regulators step up probe into bank hiring. WSJ 2014 May 8; pp. A1, 8.

[15] Levin N, Glazer E, Matthews CM. E-mails track J.P. Morgan hire in China. Wall St J 2015 February 7; pp. A1, A8.

[16] Jones A, Lublin JS. Critics blow whistle on law. Wall St J 2010 November; pp. B1, 11.

[17] Holzer J, Johnson F. Larger bounties spur surge in fraud tips. Wall St J 2010 September: p. C3.

\section{CONFLICT OF INTEREST}

The author confirms that this article content has no conflict of interest.

\begin{tabular}{lcc}
\hline Received: February 02, 2015 & Revised: March 09, 2015 & Accepted: March 11, 2015 \\
() Frank J. Cavico; Licensee Bentham Open. &
\end{tabular}

This is an open access article licensed under the terms of the Creative Commons Attribution Non-Commercial License (http://creativecommons.org/licenses/by-nc/3.0/) which permits unrestricted, non-commercial use, distribution and reproduction in any medium, provided the work is properly cited. 